\title{
Responses of Three Bromegrass (Bromus) Species to Defoliation under Different Growth Conditions
}

\author{
B. Biligetu ${ }^{1,2}$ and Bruce Coulman ${ }^{1}$ \\ ${ }^{1}$ Department of Plant Sciences, University of Saskatchewan, 51 Campus Drive, Saskatoon, SK, Canada S7N 5A8 \\ ${ }^{2}$ Semiarid Prairie Agricultural Research Centre, Agriculture and Agri-Food Canada, Swift Current, SK, Canada S9H 3X2
}

Correspondence should be addressed to Bruce Coulman, bruce.coulman@usask.ca

Received 30 June 2010; Accepted 24 August 2010

Academic Editor: Rodomiro Ortiz

Copyright (C) 2010 B. Biligetu and B. Coulman. This is an open access article distributed under the Creative Commons Attribution License, which permits unrestricted use, distribution, and reproduction in any medium, provided the original work is properly cited.

Bromegrass species are important forage crops in temperate regions of world. This study compared responses of three bromegrass species to defoliation in the greenhouse and field to determine if the former could predict responses in the latter. Experiments were conducted in 2006 and 2007 in Saskatoon (52 $07^{\prime}$ N, 106 38 ${ }^{\prime}$ W), Canada on meadow bromegrass (Bromus riparius Rehm.), smooth bromegrass (Bromus inermis Leyss.), and hybrid bromegrass (B. riparius X B. inermis) following defoliation to $5 \mathrm{~cm}$ stubble height. When defoliated at the vegetative stage, above-ground biomass was similar among the three species in the field, but meadow bromegrass produced greater above-ground biomass than smooth bromegrass in the greenhouse. When defoliated at the stem elongation stage, meadow bromegrass produced greater above-ground biomass than smooth bromegrass in both environments. In the field, for all defoliation treatments, tiller number was greatest in meadow bromegrass, intermediate in hybrid bromegrass, and least in smooth bromegrass. In the greenhouse, however, the three species did not differ in tiller number. Similar results were found for below-ground biomass. Thus, testing the effect of defoliation in the greenhouse environment did not accurately predict the effect in the field environment.

\section{Introduction}

Smooth bromegrass and meadow bromegrass are perennial, cool-season grasses widely cultivated for pasture and hay in temperate regions of world. Meadow bromegrass is well adapted to grazing due to its rapid regrowth after defoliation [1], while smooth bromegrass is intolerant to frequent defoliation and generally used for hay [2]. The hybrid bromegrass cultivar "Knowles" was recently developed by hybridizing smooth and meadow bromegrass and has potential for both hay and pasture use [3]. A number of studies have been conducted in the field to understand morphological and physiological characteristics of the three bromegrass species in response to defoliation $[1,4-7]$; however, little information is available on how these three species respond to defoliation under different growth environments.

In cool-season grasses, the optimum temperature for growth varies among species [8]. Leaf appearance and elongation rate are often reduced by low temperature and moisture level $[9,10]$. High temperature inhibits tillering because of high respiration rates and lower soluble carbohydrate concentrations in the plant [8]. The ability of grasses to produce tillers is sensitive to changes in light intensity and quality. Tiller density increases with increasing light intensity [11] and high red: far-red ratio [12]. Resource competition also affects grass growth, and tiller development is stimulated by high nutrient concentration [13]. In addition to environmental factors, time of utilization for forage also causes differences in grass regrowth due to difference in available meristems among growth stages [14]. Generally, regrowth occurs faster from elongation of existing vegetative tillers than growth of axillary buds [14, 15]. The early spring grazing of bromegrasses occurs at the vegetative growth stage, while hay harvesting occurs after stem elongation [1]. The objective of this study was to compare the growth of three bromegrass species in field and greenhouse environments following defoliation at the vegetative or stem elongation stage to determine whether field response could be predicted by studies in controlled environments. 
TABLE 1: Date of defoliation and the corresponding cumulative growing-degree-days (GDDs) between defoliation and measurement of above-ground biomass and tiller density for three bromegrasses during the summers of 2006 and 2007 in field studies at Saskatoon, Canada.

\begin{tabular}{|c|c|c|c|c|c|c|}
\hline & \multicolumn{2}{|c|}{ Date of defoliation } & \multicolumn{2}{|c|}{ Date of measurement } & \multicolumn{2}{|c|}{ GDD } \\
\hline & 2006 & 2007 & 2006 & 2007 & 2006 & 2007 \\
\hline \multicolumn{7}{|l|}{ Vegetative stage } \\
\hline All three bromegrasses & 10 May & 9 May & $1 \mathrm{Aug}$ & $13 \mathrm{Jul}$ & 1465 & 964 \\
\hline \multicolumn{7}{|l|}{ Stem elongation stage } \\
\hline Meadow bromegrass & 19 May & 25 May & $28 \mathrm{Jul}$ & $24 \mathrm{Jul}$ & 1271 & 1049 \\
\hline Smooth bromegrass & 22 May & 31 May & 1 Aug & $27 \mathrm{Jul}$ & 1304 & 1045 \\
\hline Hybrid bromegrass & 22 May & 26 May & $1 \mathrm{Aug}$ & $24 \mathrm{Jul}$ & 1304 & 1041 \\
\hline
\end{tabular}

\section{Materials and Methods}

2.1. Field Study. Field plots were located at the Agriculture and Agri-Food Canada Research Farm ( $52^{\circ} 07^{\prime} \mathrm{N}, 106^{\circ} 38^{\prime}$ W) in Saskatoon, Canada. The soil was a Dark Brown Chernozem [16]. Field studies were conducted from May to July of 2006 and 2007 in two trials consisting of meadow, smooth, and hybrid bromegrasses, which were established in 2004 and 2006, respectively. Each trial was established in a four replicate, randomized complete block design with each plot consisting of four, 6-m long rows, spaced $30 \mathrm{~cm}$ apart and seeded at a rate of 100 seeds $\mathrm{m}^{-1}$. No fertilizer was applied during the growing season in the field. Plants were clipped to $5 \mathrm{~cm}$ stubble height at the vegetative (V1) or stem elongation stage (E1) [17]. An undefoliated control was also included in all plots. Rainfall during the experiments was $225 \mathrm{~mm}$ in 2006 and $147.5 \mathrm{~mm}$ in 2007. The 30-year long-term average rainfall from AprilJuly at this site is $174 \mathrm{~mm}$. Cumulative growing degree days (GDDs) during the study were calculated using equation $\mathrm{GDD}=\sum$ (daily maximum temperature + daily minimum temperature)/2 [18] (Table 1). The base temperature of $5^{\circ} \mathrm{C}$ was used in the equation.

2.2. Field Data Collection. The number of tillers was recorded in two $15 \times 20 \mathrm{~cm}$ fixed quadrats which were randomly placed over rows in each plot before defoliation. In each year, tiller numbers were counted and regrowth harvested in these fixed quadrats after a similar number of GDD had accumulated following each defoliation (Table 1). Harvested above-ground biomass was dried at $60^{\circ} \mathrm{C}$ for $48 \mathrm{~h}$ and weighed. The areas harvested for above-ground biomass were trimmed to ground level before soil cores were taken to estimate below-ground biomass. Soil cores were $8 \mathrm{~cm}$ in diameter and $20 \mathrm{~cm}$ deep. Soil cores were washed with water under high pressure. Washed samples were dried in the oven at $80^{\circ} \mathrm{C}$ for $48 \mathrm{~h}$ and weighed.

2.3. Greenhouse Study. Sods of the three bromegrass species were transferred to the greenhouse from the field in early November of 2006 and 2007. Sods were planted in $20 \mathrm{~cm}$ pots. The experiment was a randomized-complete-blockdesign with four replicates. The space between individual pots was approximately $20 \mathrm{~cm}$. Plants were defoliated to $5 \mathrm{~cm}$ stubble height at the vegetative (V1) or stem elongation stage (E1) [17]. An undefoliated control was also included in the experiment. Light was provided by Philips SON AGRO Lamps (Philips Lighting Co.) with a day length of $16 \mathrm{~h}$ at $21^{\circ} \mathrm{C}$ and a night period of $8 \mathrm{~h}$ at $16^{\circ} \mathrm{C}$. Light intensity was $440 \pm 150 \Phi \mathrm{mol} \mathrm{s}^{-1} \mathrm{~m}^{-2}$. Sods were watered periodically when the soil surface became dry. No fertilizer was applied during the greenhouse study.

2.4. Greenhouse Data Collection. The number of initial tillers was counted in each pot before the experiment began. Final tiller number and regrowth biomass were determined in each pot after a similar number of GDD (1260) had accumulated following each defoliation. Harvested above-ground biomass was dried at $60^{\circ} \mathrm{C}$ for $48 \mathrm{~h}$ and weighed. Below-ground biomass was also determined for all samples at the end of experiment using the same procedure as for the field study.

2.5. Statistical Analysis. Above- and below-ground biomass and tiller densities were compared within each defoliation treatment by performing Proc Mixed as a one-way analysis of variance (ANOVA) using SAS 9.1.3 Proc Mixed Model [19]. Species was considered as a fixed effect, while year and block were considered random effects in the model. When ANOVA indicated significant differences $(P \leq .05)$, means were separated using the least square means comparison. Initial tiller density had an interaction effect with final tiller density in the greenhouse study, but not in the field study. Analysis of Covariance was conducted to eliminate the effects of initial tiller differences among species in the greenhouse study.

\section{Results and Discussion}

3.1. Above-Ground Biomass. The three bromegrass species produced relatively greater regrowth biomass in the greenhouse than in field (Table 2). However, the ranking of species in above-ground biomass was not the same in field and greenhouse experiments. In undefoliated growth, hybrid bromegrass produced greater above-ground biomass than meadow and smooth bromegrass in the field study, but meadow bromegrass produced greater above-ground biomass than hybrid bromegrass in the greenhouse (Table 2). Above-ground biomass was not different between meadow and smooth bromegrass in both environments. When defoliated at the vegetative stage, there was again no consistency in 
TABLE 2: Above-ground biomass $\left(\mathrm{g} \mathrm{m}^{-2}\right.$ ) of three bromegrass species after 60 days of growth in undefoliated control or following defoliation to $5 \mathrm{~cm}$ in field or greenhouse studies conducted in 2006 and 2007 at Saskatoon, Canada.

\begin{tabular}{|c|c|c|c|c|c|c|}
\hline \multirow[t]{2}{*}{ Species } & \multicolumn{2}{|c|}{ Undefoliated control } & \multicolumn{2}{|c|}{ Defoliated at vegetative stage } & \multicolumn{2}{|c|}{ Defoliated at stem elongation stage } \\
\hline & Field & Greenhouse & Field & Greenhouse & Field & Greenhouse \\
\hline Meadow bromegrass & $1039 \mathrm{~b}^{\dagger}$ & $1239 \mathrm{a}$ & $557 \mathrm{a}$ & $937 \mathrm{a}$ & $324 \mathrm{a}$ & $663 \mathrm{a}$ \\
\hline Smooth bromegrass & $1072 \mathrm{~b}$ & $1127 \mathrm{ab}$ & $493 \mathrm{a}$ & $775 \mathrm{~b}$ & $217 b$ & $561 \mathrm{~b}$ \\
\hline Hybrid bromegrass & $1224 \mathrm{a}$ & $954 \mathrm{~b}$ & $512 \mathrm{a}$ & $822 \mathrm{ab}$ & $295 \mathrm{a}$ & $551 \mathrm{~b}$ \\
\hline$P$ & .03 & .05 & .48 & .04 & .01 & .04 \\
\hline $\mathrm{SEM}^{\ddagger}$ & 203 & 79 & 85 & 85 & 74 & 86 \\
\hline
\end{tabular}

${ }^{\dagger}$ Means within a column with the same letter (a-b) are not significantly different $(P>.05)$.

* Standard error of the mean.

above-ground biomass rankings of species in field and greenhouse experiments. Regrowth was not different among the three species in the field, but meadow bromegrass produced greater regrowth than smooth bromegrass in the greenhouse (Table 2). When defoliated at the stem elongation stage, however, meadow bromegrass consistently produced greater regrowth biomass than smooth bromegrass in both field and greenhouse, and more regrowth biomass than hybrid bromegrass in the greenhouse (Table 2). Meadow bromegrass is more suitable in moist, cool environment than smooth bromegrass [1]. The greenhouse plants were provided with more consistent soil moisture than those in the field, and regrowth of meadow bromegrass may have been favored by this moisture regime, relative to the other bromegrass species. In addition, meadow bromegrass has a greater number of unelongated tillers than smooth bromegrass when defoliated after stem elongation [1]. Differences in the number of unelongated tillers after the stem elongation stage may be related to the greater regrowth of meadow bromegrass under both environments, because elongated tillers die after defoliation, and regrowth comes from unelongated tillers or axillary buds [20].

3.2. Below-Ground Biomass. In the field study, meadow bromegrass consistently produced greater below-ground biomass than smooth bromegrass in all treatments (Table 3 ). Below-ground biomass of meadow bromegrass was similar to hybrid bromegrass in the undefoliated and vegetative stage defoliation treatments but was greater than hybrid bromegrass after defoliation at the stem elongation stage. Below-ground biomass of hybrid bromegrass was greater than smooth bromegrass following defoliation at stem elongation but was similar in the other two treatments. In another field study [21], meadow bromegrass produced greater root dry matter than smooth bromegrass under low intensity grazing. In contrast to the field environment, below-ground biomass in the greenhouse was not different among the three species for any treatment (Table 3 ). In grass species, each tiller produces its own roots, and similar tiller density of these three species in the greenhouse (Table 4) may have resulted in similar below-ground biomass. Smooth bromegrass produces rapidly spreading rhizomes whereas meadow bromegrass and hybrid bromegrass have a more caespitose growth form with short rhizomes [1]. Rhizome spread of smooth bromegrass was limited by pot walls in the greenhouse, but there were no such restrictions in the field. This may result in more below-ground biomass for smooth bromegrass in a given area in the greenhouse and thus was similar to the other two species. In general, the restriction of pot walls in greenhouse may also have increased belowground biomass of all three species compared to the field (Table 3).

3.3. Tiller Density. For all three species, there was a general trend of greater number of tillers in the greenhouse than in field (Table 4). For the field study, tiller density was the greatest for meadow bromegrass, intermediate for hybrid bromegrass, and least for smooth bromegrass in all treatments (Table 4). However, the final tiller density in the greenhouse was not significantly different among the three species within any treatment. Tiller development in grasses is strongly influenced by environmental conditions. In coolseason grasses, the optimum temperature for tillering is relatively low and varies among species [8]. The temperature was set to $21 / 16^{\circ} \mathrm{C}$ (day/night) in the greenhouse, while the temperature in the field fluctuated from -3.3 to $36.5^{\circ} \mathrm{C}$ during the studies. Light intensity and quality have a major influence on tillering $[8,11,12]$, and self-shading within a dense canopy at the tiller base is associated with a decrease in tillering [22]. Light intensity in the greenhouse was $440 \pm 150 \Phi \mathrm{mol} \mathrm{s}^{-1} \mathrm{~m}^{-2}$, which was lower than the light intensity of $1500 \Phi \mathrm{mol} \mathrm{s}^{-1} \mathrm{~m}^{-2}$ or higher on a sunny day in a field environment in Saskatoon, Canada [Biligetu, unpublished data]. Relatively higher initial tiller numbers for meadow bromegrass are likely to cause shading under the low light conditions in the greenhouse, which may have restricted tillering of this species. In addition, grass tillering is associated with nutrient availability [13], and lateral buds can only elongate into tillers while the nutrient supply exceeds the requirement of existing tillers [23]. There may have been lower nutrient availability in the greenhouse due to the limitation of root proliferation in the pots [24].

\section{Conclusions}

The response of three bromegrass species to defoliation differed under field and greenhouse environments. Even though a greenhouse environment provides an opportunity 
TABLE 3: Below-ground biomass $\left(\mathrm{g} \mathrm{m}^{-3}\right)$ of three bromegrass species after 60 days growth in an undefoliated control or following defoliation to $5 \mathrm{~cm}$ in field and greenhouse studies conducted in 2006 and 2007 at Saskatoon, Canada.

\begin{tabular}{|c|c|c|c|c|c|c|}
\hline \multirow[t]{2}{*}{ Species } & \multicolumn{2}{|c|}{ Undefoliated control } & \multicolumn{2}{|c|}{ Defoliated at vegetative stage } & \multicolumn{2}{|c|}{ Defoliated at stem elongation stage } \\
\hline & Field & Greenhouse & Field & Greenhouse & Field & Greenhouse \\
\hline Meadow bromegrass & $7980 \mathrm{a}^{\dagger}$ & 18480 a & $4560 \mathrm{a}$ & 14149 a & $5650 \mathrm{a}$ & $10554 \mathrm{a}$ \\
\hline Smooth bromegrass & $5610 \mathrm{~b}$ & $16799 \mathrm{a}$ & $2740 \mathrm{~b}$ & 10949 a & $2870 \mathrm{c}$ & 8356 a \\
\hline Hybrid bromegrass & $6430 \mathrm{ab}$ & $17882 \mathrm{a}$ & $3660 \mathrm{ab}$ & $12280 \mathrm{a}$ & $4050 \mathrm{~b}$ & $7840 \mathrm{a}$ \\
\hline$P$ & .03 & .93 & .01 & .51 & $<.01$ & .52 \\
\hline $\mathrm{SEM}^{\ddagger}$ & 600 & 3748 & 720 & 2500 & 510 & 1589 \\
\hline
\end{tabular}

${ }^{\dagger}$ Means within a column with the same letter $(\mathrm{a}-\mathrm{b})$ are not significantly different $(P>.05)$.

${ }^{\ddagger}$ Standard error of the mean.

TABLE 4: Final tiller density (tillers $\mathrm{m}^{-2}$ ) of three bromegrass species after 60 days of growth in the field for undefoliated control or following defoliation to $5 \mathrm{~cm}$ at two stages of growth in 2006 and 2007 at Saskatoon, Canada.

\begin{tabular}{|c|c|c|c|c|c|c|}
\hline \multirow[t]{2}{*}{ Species } & \multicolumn{2}{|c|}{ Undefoliated control } & \multicolumn{2}{|c|}{ Defoliated at vegetative stage } & \multicolumn{2}{|c|}{ Defoliated at stem elongation stage } \\
\hline & Field & Greenhouse & Field & Greenhouse & Field & Greenhouse \\
\hline Meadow bromegrass & $2000 \mathrm{a}^{\dagger}$ & $6500 \mathrm{a}$ & $2107 \mathrm{a}$ & $6067 \mathrm{a}$ & $1320 \mathrm{a}$ & $3833 \mathrm{a}$ \\
\hline Smooth bromegrass & $1200 \mathrm{c}$ & $5367 \mathrm{a}$ & $1093 \mathrm{c}$ & $5500 \mathrm{a}$ & $520 \mathrm{c}$ & $3500 \mathrm{a}$ \\
\hline Hybrid bromegrass & $1520 \mathrm{~b}$ & $5800 \mathrm{a}$ & $1547 \mathrm{~b}$ & $5533 \mathrm{a}$ & $840 \mathrm{~b}$ & $3467 \mathrm{a}$ \\
\hline$P$ & $<.01$ & .12 & $<.01$ & .40 & $<.01$ & .54 \\
\hline $\mathrm{SEM}^{\ddagger}$ & 222 & 312 & 74 & 287 & 57 & 950 \\
\hline
\end{tabular}

${ }^{\dagger}$ Means within a column with the same letter (a-b) are not significantly different $(P>.05)$.

‡Standard error of the mean.

$\S$ Final tiller number in the greenhouse was adjusted by analysis of covariance.

to study responses of bromegrasses to defoliation under controlled environmental conditions, it was not predictive of responses to defoliation in the field. This may be due to low light intensities in the greenhouse and restrictions in lateral growth imposed by the walls of the greenhouse pots. The latter would likely have a greater effect on grass species that produce long rhizomes.

\section{Acknowledgments}

Technical assistance of Cheryl Duncan and Tim Nelson is gratefully acknowledged. This paper was funded by Agriculture and Agri-Food Canada and the University of Saskatchewan.

\section{References}

[1] R. P. Knowles, V. S. Baron, and D. H. McCartney, Meadow Bromegrass, vol. 188/E, Agriculture Canada Publ., Ottawa, Canada, 1993.

[2] M. D. Casler and I. T. Carlson, "Smooth bromegrass," in Forages: An Introduction to Grass Land Agriculture, R. F. Barnes, et al., Ed., vol. 1, pp. 313-324, Iowa State University Press, Ames, Iowa, USA, 5th edition, 1995.

[3] B. Coulman, "Knowles hybrid bromegrass," Canadian Journal of Plant Science, vol. 84, no. 3, pp. 815-817, 2004.

[4] G. A. Van Esbroeck, V. S. Baron, and J. R. King, "Regrowth of bromegrass species, a bromegrass interspecific hybrid, and meadow foxtail in a short-season environment," Agronomy Journal, vol. 87, no. 2, pp. 244-251, 1995.
[5] W. P. McCaughey and R. G. Simons, "Harvest management and N-fertilization effects on yield and regrowth of smooth bromegrass, crested wheatgrass, and meadow bromegrass in the eastern prairies," Canadian Journal of Plant Science, vol. 76, no. 4, pp. 773-782, 1996.

[6] J. R. Pearen and V. S. Baron, "Productivity, and composition of smooth and meadow bromegrass mixtures with alfalfa under frequent cutting management," Canadian Journal of Plant Science, vol. 76, no. 4, pp. 763-771, 1996.

[7] H. A. Lardner, S. B. M. Wright, and R. D. H. Cohen, "Assessing eight grass species for pasture by measuring etiolated spring regrowth," Canadian Journal of Plant Science, vol. 83, no. 3, pp. 551-554, 2003.

[8] R. H. M. Langer, How Grasses Grow, Edward Arnold, London, UK, 1972.

[9] W. W. Wilhelm and G. S. McMaster, "Importance of the phyllochron in studying development and growth in grasses," Crop Science, vol. 35, pp. 1-3, 1995.

[10] F. Volaire, H. Thomas, N. Bertagne, E. Bourgeois, M.-F. Gautier, and F. Lelièvre, "Survival and recovery of perennial forage grasses under prolonged Mediterranean drought: II. Water status, solute accumulation, abscisic acid concentration and accumulation of dehydrin transcripts in bases of immature leaves," New Phytologist, vol. 140, no. 3, pp. 451-460, 1998.

[11] J. W. Ashmun and L. F. Pitelka, "Light-induced variation in the growth and dynamics of transplanted ramets of the understory herb, Aster acuminatus," Oecologia, vol. 64, no. 2, pp. 255-262, 1984.

[12] J. J. Casal, R. A. Sanchez, and V. A. Deregibus, "Tillering responses of Lolium multiflorum plants to changes of red/far red ratio typical of sparse canopies," Journal of Experimental Botany, vol. 38, pp. 1432-1439, 1987. 
[13] G. R. Shaver, F. S. Chapin III, and B. L. Gartner, "Factors limiting seasonal growth and peak biomass accumulation in Eriophorum vaginatum in Alaskan tussock tundra," Journal of Ecology, vol. 74, no. 1, pp. 257-278, 1986.

[14] D. D. Briske, "Plant response to defoliation: morphological considerations and allocation priorities," in Rangelands: $A$ Resource under Siege, P. J. Joss, P. W. Lynch, and O. B. Williams, Eds., pp. 425-427, Aust. Acad. Sci., Canberra, Canada, 1986.

[15] D. N. Hyder, "Defoliation in relation to vegetative growth," in The Biology and Utilization of Grasses, V. B. Youngner and C. M. McKell, Eds., pp. 302-317, Academic Press, New York, NY, USA, 1972.

[16] W. K. Head, Soil Resources of the Saskatoon Region, Saskatchewan Institute of Pedology Publ. M47, Saskatoon, Canada, 1979.

[17] K. J. Moore and L. E. Moser, "Quantifying developmental morphology of perennial grasses," Crop Science, vol. 35, pp. 37-43, 1995.

[18] A. B. Frank and L. Hofmann, "Relationship among grazing management, growing degree-days, and morphological development for native grasses on the Northern Great Plains," Journal of Range Management, vol. 42, no. 3, pp. 199-202, 1989.

[19] SAS Institute, Statistical Analysis System Version 9.1, SAS Institute Inc., Raleigh, NC, USA, 2003.

[20] I. Davies, "Developmental characteristics of grass varieties in relation to their herbage production II. Spring defoliation of Dactylis glomerata: the fate of reproductive tillers which are cut, but whose stem apex is retained," Journal of Agricultural Science, vol. 87, pp. 8-33, 1976.

[21] E. Mapfumo, M. A. Naeth, V. S. Baron, A. C. Dick, and D. S. Chanasyk, "Grazing impacts on litter and roots: perennial versus annual grasses," Journal of Range Management, vol. 55, no. 1, pp. 16-22, 2002.

[22] S. Kays and J. L. Harper, "The regulation of plant and tiller density in a grass sward," Journal of Ecology, vol. 62, pp. 97$105,1974$.

[23] F. G. Gregory and J. A. Veale, "A reassessment of the problem of apical dominance," Symposia of the Society for Experimental Biology, vol. 2, pp. 1-20, 1957.

[24] M. M. Caldwell, "Plant requirements for prudent grazing," in Developing Strategies for Rangeland Management. NRC/NAS Report, pp. 117-152, Westview Press, Boulder, Colo, USA, 1984. 


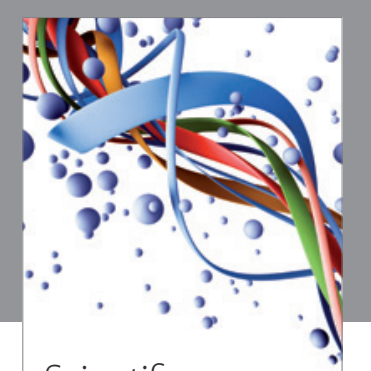

Scientifica
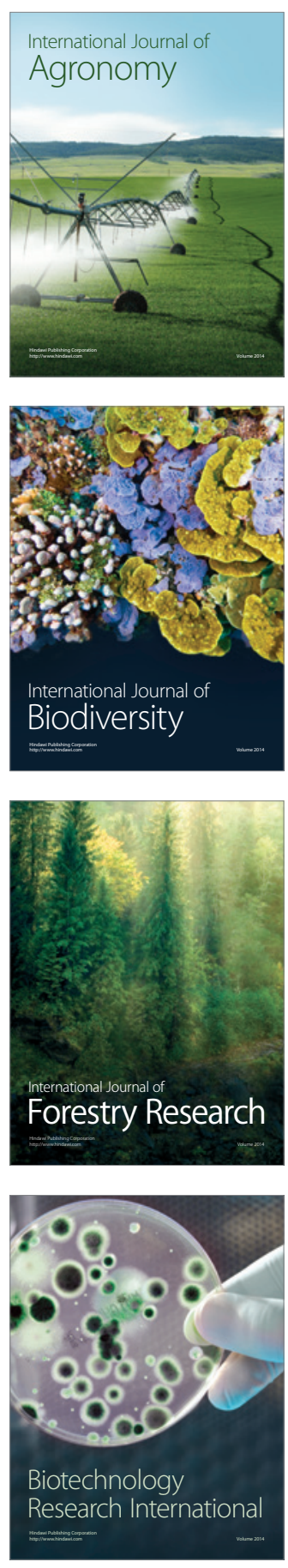
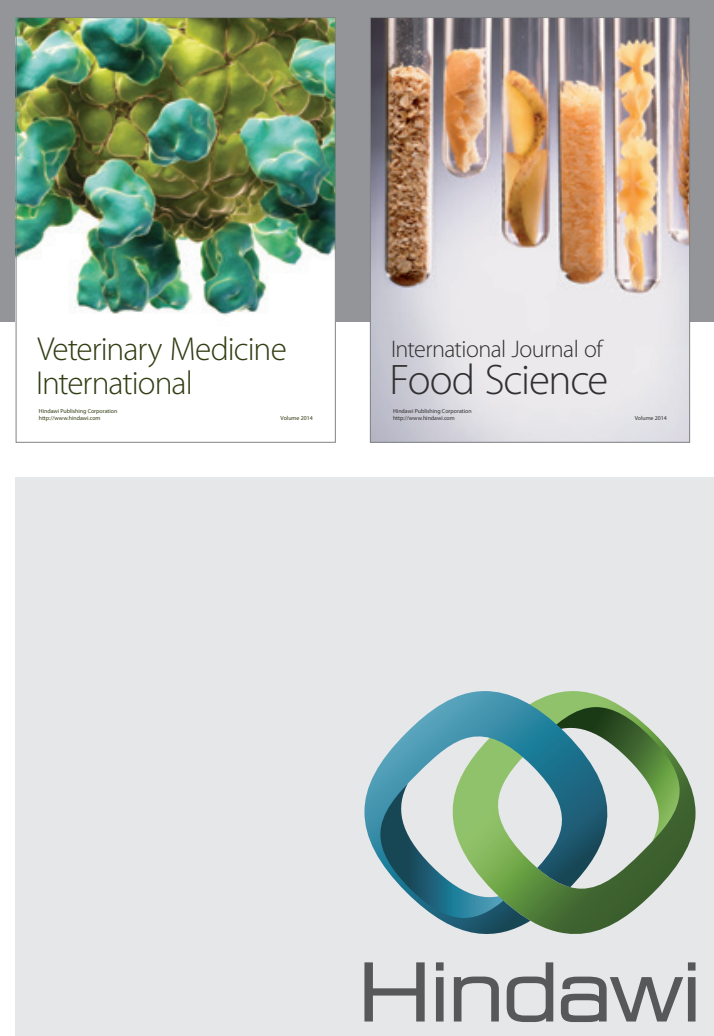

Submit your manuscripts at

http://www.hindawi.com
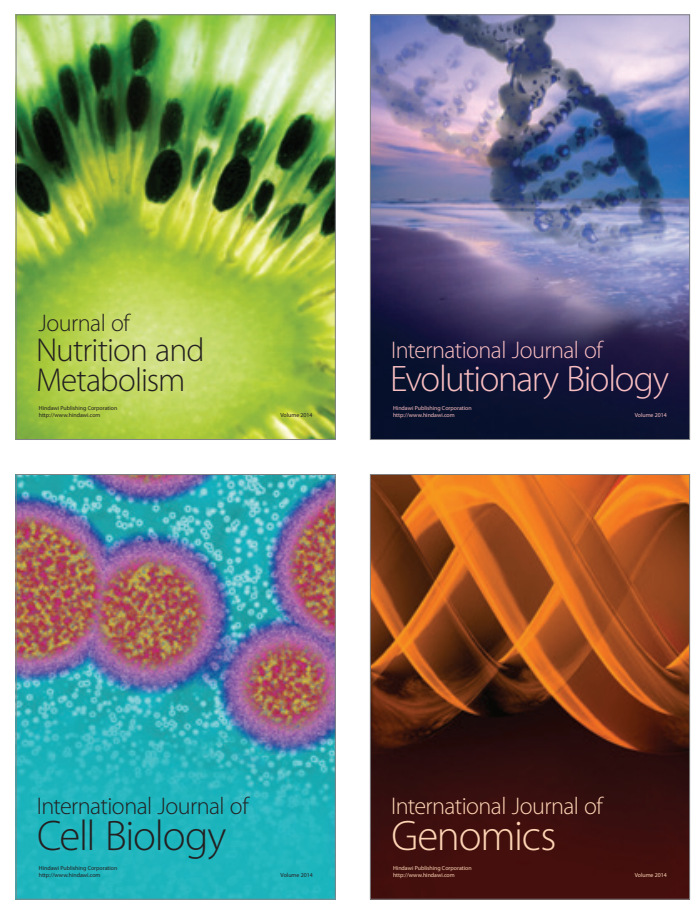
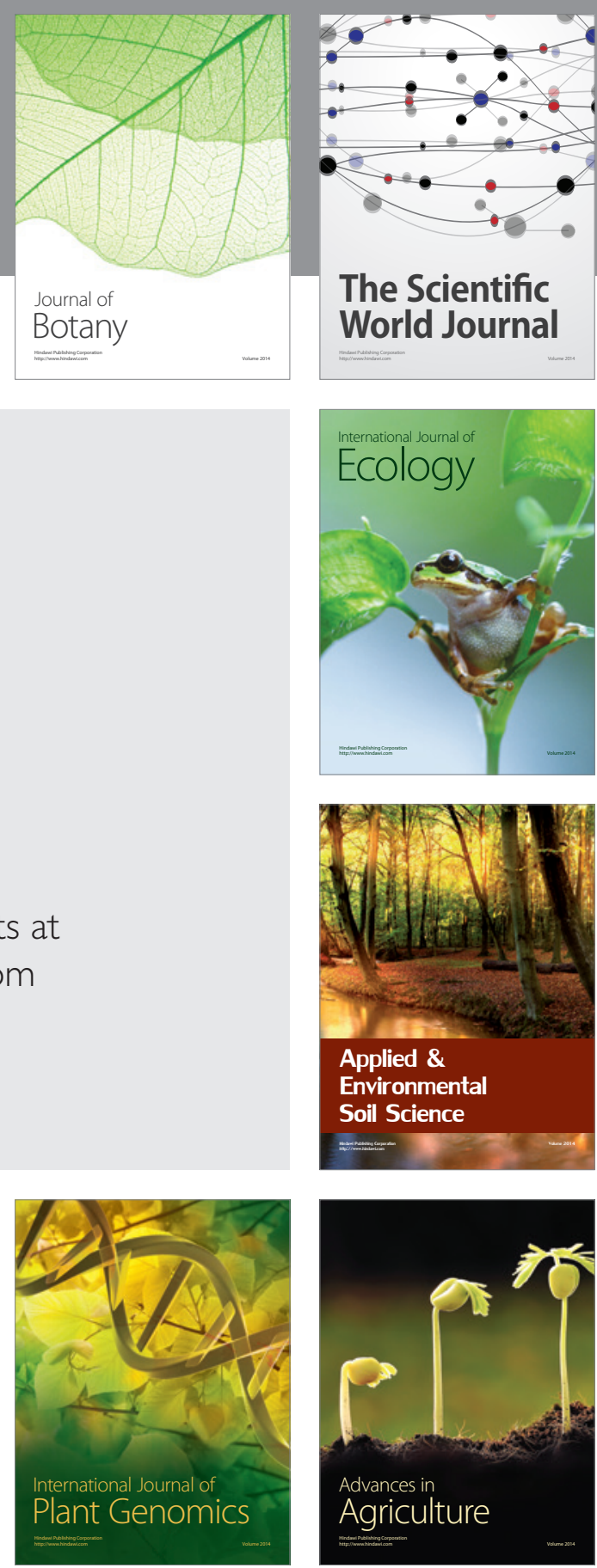

The Scientific World Journal
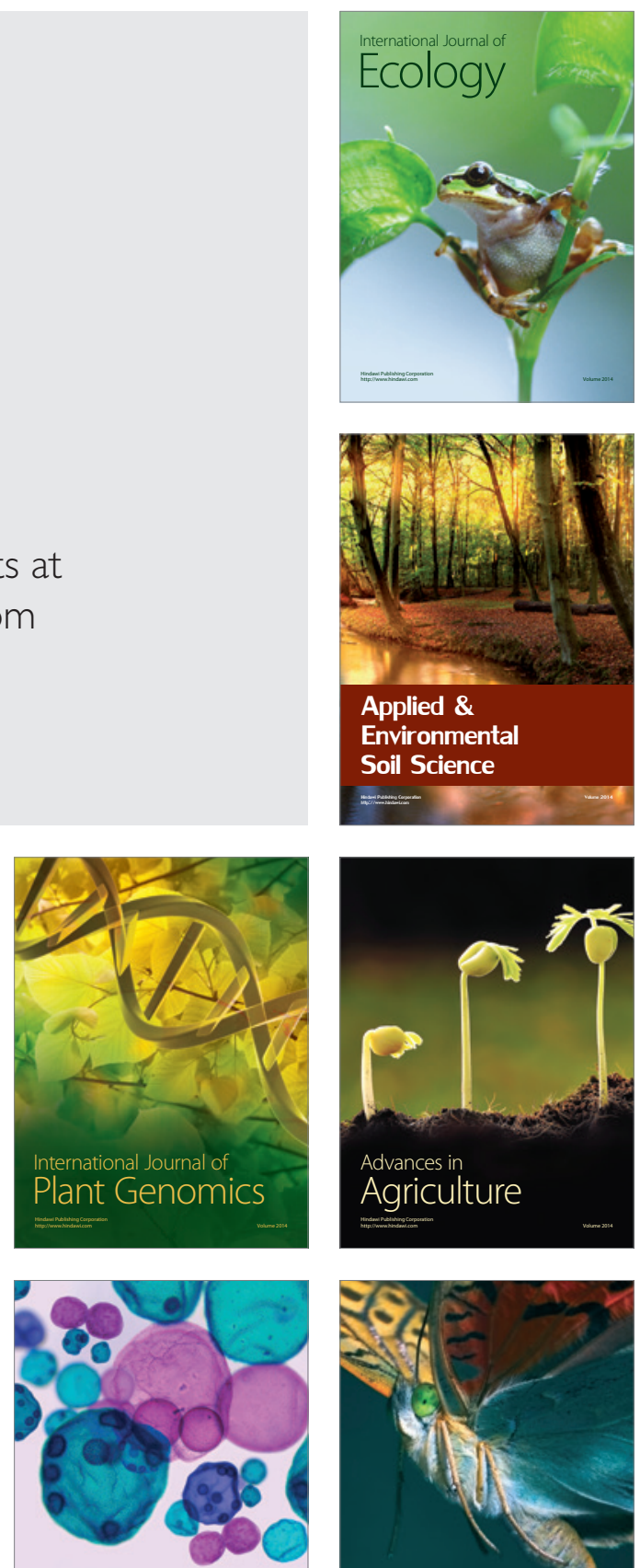

International Journal of Microbiology

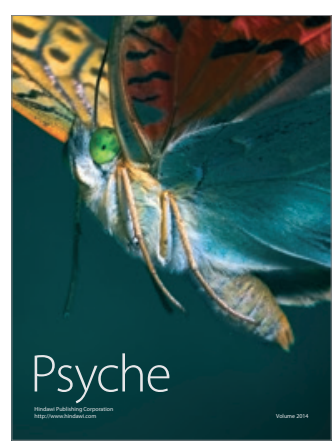

